Expression of antiviral gene on tiger shrimp at different tissue ... (Andi Parenrengi)

\title{
EXPRESSION OF ANTIVIRAL GENE ON TIGER SHRIMP Penaeus monodon AT DIFFERENT TISSUE AND BODY SIZE
}

\author{
Andi Parenrengi\#, Andi Tenriulo, and Samuel Lante \\ ${ }^{*}$ Research and Development Institute for Coastal Aquaculture, Maros
}

(Received 3 September 2012; Accepted 5 November 2012)

\begin{abstract}
The role of tiger shrimp defense against invading pathogen on molecular level such antiviral gene expression is limited to be reported. Gene expression is a process which codes information of genes that is converted to the protein as a phenotype. Distribution of PmAV antivirus gene, that has been reported as an important gene on non-specific response immune, is needed to be observed to several organs/tissues and size of tiger shrimp. The aim of this study is to determine the distribution of gene antiviral expression at several organ/tissue and size of shrimp. The organs/tissues observed in this study were: gill, hepatopancres, muscle tissue, eyes, heart, stomach, gonad, and intestine. While the size of shrimp consisted of three groups, those are: (A) $10-20 \mathrm{~g} /$ ind., (B) $30-40 \mathrm{~g} /$ ind., and (C) $60-70 \mathrm{~g} /$ ind. Analysis of antiviral gene expression was performed by RNA extraction, followed by the cDNA syntesis, and amplification of gene expression by semi-quantitative PCR. The result of PCR optimation showed the optimal concentration of cDNA and primer was $1 \mu \mathrm{L}$ and 50 $\rho$ mol, respectively for PCR final volume of $25 \mu \mathrm{L}$. Antiviral gene was expressed on the hepatopancreas and stomach in percentage of $50.0 \%$ and $16.7 \%$ respectively. While the highest percentage of individual expressing the antiviral gene was observed in the shrimp size of C (66.7\%), followed by B $(50.0 \%)$ and $A(16.7 \%)$. The result of study implied that the hepatopancreas has importantly involed in tiger shrimp defense mechanism on viral infection.
\end{abstract}

KEYWORDS: tiger shrimp, gene expression, antiviral, organ tissue, size

\section{INTRODUCTION}

The serious problems faced by farmers of tiger shrimp Penaeus monodon since the mid of 1990's is the presence of invasive disease caused by viral infection. Until now, in Indonesia, eight kinds of virus have been reported to infect the tiger shrimp, namely: baculo monodon virus (MBV), infectious hypodermal hematophoitic necrosis virus (IHHNV), hepatopancreatic parvo-like virus (HPV), baculovirus midgut gland necrosis virus (BMNV), type C- baculovirus (TCBV), yellow head virus baculo (YHBV), taura syndrome virus (TSV) and white spot syndrome virus (WSSV) (Anonymous, 2003). Among of them, viral pathogen of WSSV is most often found as the cause of white spot disease in shrimp aquaculture.

The aggression of WSSV infection in cultured penaeid shrimp could not be optimally solved. Various mitigation efforts have been made to overcome the disease, such as: the provision of immunostimulants, vaccines, selection, and genetic engineering. The development of molecular technique provides great

\# Corresponding author. Research and Development Institute for Coastal Aquaculture JI. Makmur Dg. Sitakka No. 129, Maros 90512, Sulawesi Selatan, Indonesia. Tel.: +62 411371544 E-mail address: andi_parenrengi@hotmail.com 
opportunities to study the body's defense mechanism of shrimp against WSSV infection. Luo et al. (2003) first isolated the virus Penaeus monodon antiviral genes, called PmAV from tiger shrimp on aquaculture farm in China. This gene is known to play a role in the immune system in black tiger shrimp. Furthermore, in Indonesia, Parenrengi (2010) have successfully isolated, cloned and transferred to into shrimp embryos. The latest finding showed that diseases resistance of tiger shrimp to WSSV could be increased through transfering PmAV antiviral gene by gene transfection technique.

PCR (Polymerase Chain Reaction) technique is commonly used in conducting studies on the molecular level, such as genetic diversity, disease detection, and gene expression. The high PCR sensitivity is consequencely needed for parameter optimization that affect the amplification of the target DNA fragment. PCR analysis has a high sensitivity to the reaction conditions, and the changes in these conditions impact the results of DNA amplification, so that the PCR optimization needs to be done in order to obtain the optimal parameters in the amplification of gene expression.

The research of antimicrobial gene expression could be performed by utilizing amplification PCR using CDNA as template DNA, and also by the analysis of the formation of peptide protein from antiviral gene. Gene expression is known as the process by which codes information contained in genes is converted into proteins that operate in the cell. So the process of gene expression is a series of translation of genetic information (in the form of base sequences in DNA or RNA) into protein, or as further known as phenotype. Information of genetic material is not useful for an organism if it is not expressed a phenotype. Studies of gene expression is widely conducted, not only to determine the level of immunity in fish or shrimp, but also to determine the impact of pollution on ecosystems, for example the expression of heat shock protein indicators 90 (HSP90) in fish Mugil cephalus (Padmini et al., 2008 ). Detection of increasement the body's defense of shrimp against WSSV through the study of gene expression of PAP (phogositosis activating protein) has been carried out by Deachamag et al. (2006). Cytokine gene expression has been reported to play an important role in immunity in the zebrafish Danio rerio (Ito et al., 2008). In goldfish, ghrelin gene expression in carp Cyprinus capio closely associated with the stimulation of immune activation (Kono et al., 2008), where expression of the gene was distributed in multiple organs, namely the intestine, spleen, and brain of goldfish.

Shrimp antiviral gene, PmAV has been isolated from shrimp hepatopancreas (Luo et al., 2007; Parenrengi, 2010). The success work is the useful reference in assessment of regarding to the immune system and the body's defense mechanisms against pathogens by tiger shrimp. The host defense mechanisms such cellular and humoral reactions in shrimp include phagocytosis, encapsulation, nodule formulation, clotting, agglutination, prophenoloxidase (proPO) cascade and antimicrobial activity (Somboonwiwat et al., 2006). In addition, the expression of antiviral genes may be used as a marker in assisting the breeding selection as known as MAS (marker assisted selection). Studies of gene expression in especially on various tissues (organs) and size of the shrimp can be used as a reference for studying the mechanism of shrimp patterns defense against disease- causing pathogens. Therefore, the study antiviral gene was conducted in order to determine the distribution of antiviral gene expression in various tissues (gills, hepatopancreas, meat, eyes, heart, stomach, gonads, and intestines) and the size of the shrimp. The results of this study will provide data and information on the pattern of the naturally body's defense of tiger shrimp and can be taken into consideration in an effort to increase the resistance to WSSV diseases.

\section{MATERIAL AND METHOD}

\section{Tiger Shrimp Sample}

Test animals used in this study were cultured shrimp from pond aquaculture in Maros, South Sulawesi in an average weight of $34.3 \pm 3.0 \mathrm{~g}$, and the average length of $15.9 \pm 0.6$ $\mathrm{cm}$ for 6 samples ( 3 males and 3 females). The expression of antiviral genes in various sizes was categorized by three groups of body weight, namely: $A=10-20 \mathrm{~g}$ ( 3 males and 3 females), $\mathrm{B}=30-40 \mathrm{~g}$ ( 3 males and 3 females), and $\mathrm{C}=60-70 \mathrm{~g}$ ( 2 males and 4 females). Shrimp samples are collected a life and transported to the laboratory for RNA extraction. Samples of tissues shrimp analyzed in this study were: gills, hepatopancreas, muscle, eyes, heart, stomach, gonad, and intestine. 
Expression of antiviral gene on tiger shrimp at different tissue ... (Andi Parenrengi)

\section{Total RNA Extraction}

Total RNA was extracted using isogen kit (Nippon Gene) by procedure as described by Parenrengi et al. (2009). A total of 10- $25 \mathrm{mg}$ samples of tissues was aseptically removed from the tiger shrimp into the $1.5 \mathrm{~mL}$ microtube, and then dissolved in $200 \mathrm{~mL}$ isogen in a container filled with ice. The crushed sample with a grinder microtube isogen was added again with isogen up to $800 \mathrm{~mL}$, and then incubated at room temperature for 5 minutes until the sample completely lysis. The sample is added with $200 \mathrm{~mL}$ of chloroform and mixed the solution by vortexing and allowed to room temperature for 2- 3 minutes. Samples were centrifuged at $12,000 \mathrm{rpm}$ for $10 \mathrm{~min}$. and then stored at room temperature for $5 \mathrm{~min}$., and the supernatant was transferred into a new microtube filled with $400 \mathrm{~mL}$ iso-propanol. Samples were homogenized with shaking gently and then stored at room temperature for 5- $10 \mathrm{~min}$. Samples were centrifuged again at a speed of $12,000 \mathrm{rpm}$ at $4^{\circ} \mathrm{C}$ for $15 \mathrm{~min}$. Supernatant was discarded, while the pellet was dissolved with $1 \mathrm{~mL}$ of $70 \%$ cold- ethanol and then centrifuged at a speed of 12,000 $\mathrm{rpm}$ at $4^{\circ} \mathrm{C}$ for $15 \mathrm{~min}$. Supernatant was discarded, and then pellet was dried. RNA pellet was dissolved with $50 \mathrm{~mL}$ of $0.1 \%$ DEPC and followed measurement of concentration and purity of RNA by GenQuant prior to CDNA synthesis.

\section{RT- PCR for CDNA Synthesis}

Synthesis of complementary DNA (cDNA) was performed using a kit of Ready-To-Go You- Prime Fisrt Strand Beads (GE Healthcare) with the RT- PCR technique (Reversed Transcription- PCR). RNA concentration of $3 \mathrm{mg}$ in $30 \mathrm{~mL}$ of $0.1 \%$ DEPC was homogenized by vortexing in the microtube, and then incubated at $65^{\circ} \mathrm{C}$ for 10 minutes. Furthermore, microtubes was put in ice for 2 minutes, then RNA is inserted into the tube first strand reaction mix beads which al ready contains 2 grains of white balls. Three microlitres of oligo (dT) primer 5'- gta ata ata cga act ata ggg cac tcg acg tgg gcg gct cgg gcc ggt ttt ttt ttt ttt ttt t- '3 in concentration of $1 \mu \mathrm{g} / 3 \mu \mathrm{L}$ were added into the reaction, and then left to stand for 1 minute. Micro tubes were incubated at $37^{\circ} \mathrm{C}$ for 1 hour, then the formed cDNA was added with $50 \mathrm{~mL}$ SDW (sterile distillated water).

\section{PCR Optimization}

Optimization of PCR was done in order to get the clear target DNA fragment. Amplification was performed on PCR GenAmp 2700 (Applied Biosystems). PCR process was run on predenaturation temperature of $94^{\circ} \mathrm{C}$ for $2 \mathrm{~min}$.; 35 cycles for (denaturation $94^{\circ} \mathrm{C}$ for 30 seconds, annealing $61^{\circ} \mathrm{C}$ for 30 seconds, extension $72^{\circ} \mathrm{C}$ for 45 seconds), and final extension of $72^{\circ} \mathrm{C}$ for 7 minutes. Optimization of PCR parameters were performed on primer concentration of 50 and $60 \mathrm{pmol} / \mathrm{mL}$ and cDNA of $0.5 ; 1.0 ; 1.5$; and $2.0 \mathrm{~mL}$.

\section{Isolation and Analysis of Antiviral Gene Expression}

Isolation of antiviral genes PmAV was performed using cDNA as template DNA and using specific primers based on sequences deposited at GenBank at accession number AY302750.1 (Luo et al., 2003). The primers were PmAV-F 5'- tgc tag atg atg ggt cat cat aca atc cta- 3 'and PmAV- R 5' - tct ctg tgt atg cct cga gct gct ttc aca- 3', with a target fragment approximately $513 \mathrm{bp}$. One milligram of cDNA used as a template for PCR using kit PureTaq Ready- ToGo PCR Beads (GE Healthcare), and mixed with $1 \mathrm{~mL}(50 \mathrm{\rho mol} / \mathrm{mL}$ ) for each forward and reverse primer, and then added up to $25 \mathrm{~mL}$ SDW. The kit contained 2.5 units of Taq polymerase, $10 \mathrm{mM}$ Tris- $\mathrm{HCl} \mathrm{pH} \mathrm{9,50} \mathrm{mM} \mathrm{KCl;} 1.5 \mathrm{mM} \mathrm{MgCl}$, and $200 \mu$ M each dNTP- mix.

Amplification of antiviral gene was performed on GenAmp 7200 PCR machine (Applied Biosystems). PCR process was run on pre- denaturation temperature of $94^{\circ} \mathrm{C}$ for $2 \mathrm{~min}$; 35 cycles for $\left(94^{\circ} \mathrm{C}\right.$ denaturation for 30 seconds, annealing $60^{\circ} \mathrm{C}$ for 30 seconds, extension $72^{\circ} \mathrm{C}$ for 45 seconds), and final extension of $72^{\circ} \mathrm{C}$ for 7 minutes. While the $\beta$-actin gene amplification was performed by PCR on the program as follows: pre- denaturation of $94^{\circ} \mathrm{C}$ for 2 min.; 35 cycles for (denaturation $94^{\circ} \mathrm{C}$ for 30 seconds, annealing $55^{\circ} \mathrm{C}$ for $30 \mathrm{sec}-$ onds, extension $68^{\circ} \mathrm{C}$ for $1 \mathrm{~min}$.), and final extension of $68^{\circ} \mathrm{C}$ for 5 minutes. To determine the successful amplification of the target DNA fragments, PCR result was electrophoresed on $1.0 \%$ agarose gel and documented with a Gel Documentation System (Biometra). Molecular weight of DNA fragment was determined by using a marker of 100 bp Plus DNA Ladder (Vivantis). 


\section{Data Analysis}

Data from PCR parameter optimization results are descriptively presented. The gene expression antivirus was analyzed based on the presence and pattern/thickness of shrimp antiviral gene expression at various tissues and size of tiger shrimp. The successful isolation of antiviral gene expression was determined by the presence of shrimp $\beta$ - actin gene expression as an internal control.

\section{RESULT AND DISCUSSION}

\section{Total RNA Isolation}

Total RNA was succesfully isolated from black tiger shrimp with a high degree of purity, such as $1.8 \pm 0.01$ on the size of body weight and $1.7 \pm 0.10$ in various tissues. For the purposes of molecular analysis, Linacero et al. (1998) has suggested the level of total RNA purity $\left(A_{260} / A_{280}\right)$ should be in the range of 1.8 to 2.0. Protein contamination was indicated by the low value of DNA purity $(<1.8)$ or while phenol contamination and other organic material were indicated by the high value of the ratio $(>2.0)$. The purity of RNA is needed in order to obtain the accurate data in determining the expression of antiviral genes. Although the total RNA has high purity, PCR otimization still need to be done to obtain the optimal parameter in determining the expression of shrimp antiviral genes.

\section{PCR Optimization}

Optimization of primer and CDNA was made to obtain optimal PCR conditions to produce specific PCR products, which formed thick and clear DNA band with expected size (the posi- tion of the DNA fragment) and did not form smear and background fragments that interfere with visualization of the target gene. Treatment of primer concentration in the PCR process may affect the results of the DNA fragments generated. Primer concentration optimization results indicated that the primer difference in concentration resulted in different outcomes amplification of target DNA fragments (Figure 1). These results indicated that the use of a concentration of $50 \mathrm{pmol} / \mathrm{mL}$ was better than the $60 \mathrm{\rho mol} / \mathrm{mL}$, whereas in the treatment of 60 pmol/ $\mathrm{mL}$, DNA fragments were thicker but smearing background along the lines of the movement of the gel, while the concentration of $50 \mathrm{\rho mol} / \mathrm{mL}$ provided a clean and sharp DNA fragment. Therefore, the primer concentration of $50 \mathrm{pmol} / \mathrm{mL}$ was selected to use in further studies for isolation all samples on gene expression in various organs and sizes of tiger shrimp. Similar result was also reported by Parenrengi (2010) using $1 \mathrm{~mL}(50 \mathrm{\rho mol} / \mathrm{mL})$ of each forward and reverse primers with a final volume of $25 \mathrm{~mL}$. According to Qiagen (1997) a primary concentration ranging between 0.1 to $0.5 \mathrm{mM}$ in the amplification reaction provided optimal results with specific PCR product. However, Yuwono (2005) states that concentrations up to $1 \mu \mathrm{M}$ primer can still produce a specific product, but the primer concentration higher than $1 \mu \mathrm{M}$ can lead to the accumulation of non-specific polymerization results. Primer concentrations lower than this optimization results such $25 \mathrm{\rho mol}$ reported by Arenal et al. (2008) in a study of growth hormone gene expression in white shrimp Litopenaeus schmitti.

Concentration of cDNA can affect the results of amplification of the target DNA fragment. The results of electrophoresis of PCR

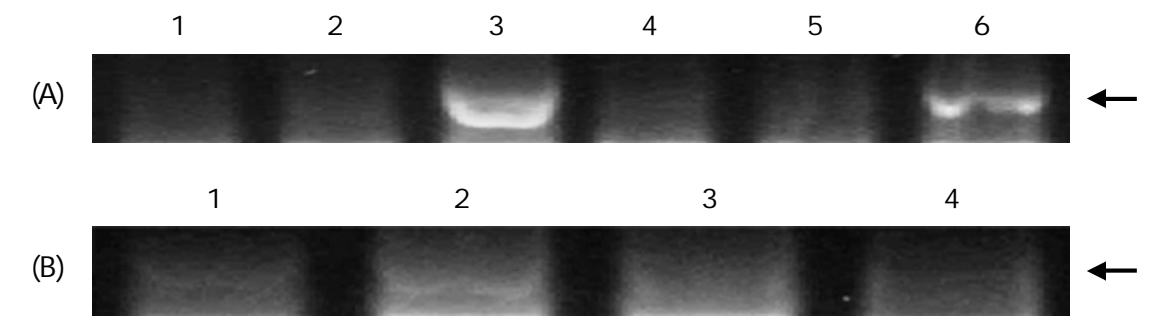

Figure 1. Electrophoresis result of optimalization of primer and cDNA concentration used for antiviral gene amplification. (A) primer concentration of $60 \rho \mathrm{mol}$ (1-3) and 50 pmol (4-6), where lane 1, 2, 4, and 5 = hepatopancreas without expressing an antiviral gene, while 4 and $6=$ hepatopancreas expressing an antiviral gene. (B) cDNA concentration of $0.5 \mu \mathrm{L}(1) ; 1.0 \mu \mathrm{L}$ (2); $1.5 \mu \mathrm{L}$ (3); and $2.0 \mu \mathrm{L}$ (4). The arrow indicating the fragment position of antiviral gene PmAV at approximately $513 \mathrm{bp}$ 
Expression of antiviral gene on tiger shrimp at different tissue ... (Andi Parenrengi)

products showed that the concentration of cDNA fragments of $1.0 \mathrm{~mL}$ has a more decisive and clear compared to other cDNA concentration. Concentration of $0.5 \mathrm{~mL}$ cDNA fragments that have too thin, while the concentration of cDNA with $1.5 \mathrm{~mL}$ and $2.0 \mathrm{~mL}$ showed no amplification or un- clear fragment (Figure 1). Sunandar et al. (2010) suggested that small concentrations of DNA templates reduced the chances of primer to the template. Therefore, the concentration of DNA in the PCR reaction component needed to be optimized to obtain consistent amplification result. Too little or too high template DNA concentration will affect the result of amplification. No amplification of high concentration of DNA is resulted by no attachment on primer sites. One of the reasons is low quality of DNA containing contaminants such as phenols and other metabolites, proteins remaining in the DNA template. The high contaminants could significantly affect the attachment of primer template of DNA (Weeden et al., 1992). Therefore, among the two main parameters showed that the optimal concentration of primers and CDNA were obtained 50 $\rho \mathrm{mol}$ and $1.0 \mathrm{~mL}$, respectively. This concentration is used as a reference for PCR amplification to determine the expression of antiviral genes and $\beta$-actin in all samples of tiger shrimp.

\section{Disribution of Antiviral Gene Expression on Various Tissues}

Expression of tiger shrimp antiviral gene in various tissues and the percentage were presented in Table 1 . Indicator of expressed or not antiviral genes used in this study was $\beta$ actin gene expression of tiger shrimp. The $\beta$ - actin gene was always expressed all times and in all organs of tiger shrimp, so that an expression of $\beta$-actin can be used as an internal control on the expression of other genes. Two of the eight organs and tissues analyzed, such as the hepatopancreas and stomach showed expression of antiviral genes. The percentage of both organs from the total samples was $50.0 \%$ in the hepatopancreas and $16.7 \%$ in the stomach. Antiviral gene expression on hepatopancreas was obtained in female and male tiger shrimp $(33.3 \%)$ and the female tiger shrimp $(66.7 \%$, while gene expression in the stomach only found in female shrimp.

Table 1 showed that antiviral gene expression of female shrimp was $66.7 \%$ in hepatopancreas and $33.3 \%$ in stomach, whereas other organs did not express the PmAV gene. In the male tiger shrimp, antiviral gene was only expressed in the hepatopancreas $(33.3 \%$. This result suggested that the expression of antiviral genes was commonly performed in hepatopancreas. Although, it was suspected that there was no difference in the immune system between male and female shrimps, but the result of this study suggested that the expression of antiviral gene was observed in stomach female shrimp, but not in male shrimp. Therefore, the further study is needed more depth on the large number of samples in learning more the role of the stomach in the shrimp immune system.

Observation of PmAV gene expression pattern showed that the greatest organ expressing antiviral gene was hepatopancreas $(50.0 \%$ followed by stomach (16.7\%) of the total

Table 1. Expression of PmAV gene antiviral isolated from several organs/tissues of tiger shrimp Penaeus monodon

\begin{tabular}{|c|c|c|c|c|c|c|c|c|c|c|}
\hline \multirow{2}{*}{ Sex } & \multirow{2}{*}{$\begin{array}{l}\text { Weight }(\mathrm{g}) / \\
\text { Length }(\mathrm{cm})\end{array}$} & \multicolumn{8}{|c|}{ Gene expression in tissues*) } & \multirow{2}{*}{$\begin{array}{c}\text { Gene expression } \\
(\%)\end{array}$} \\
\hline & & 1 & 2 & 3 & 4 & 5 & 6 & 7 & 8 & \\
\hline \multirow{3}{*}{ Female } & $32.8 / 15.7$ & - & - & + & - & - & + & - & - & Hepatopancreas (66.7) \\
\hline & $30.4 / 15.0$ & - & - & + & - & - & - & - & - & \\
\hline & $36.9 / 16.6$ & - & - & - & - & - & - & - & - & Stomach (33.3) \\
\hline \multirow{3}{*}{ Male } & $35.9 / 16.0$ & - & - & + & - & - & - & - & - & \\
\hline & $32.0 / 15.5$ & - & - & - & - & - & - & - & - & Hepatopancreas (33.3) \\
\hline & $37.9 / 16.6$ & - & - & - & - & - & - & - & - & \\
\hline
\end{tabular}

*) 1 = Muscle; 2 = Gonad; 3 = Hepatopancreas; 4 = Gill; 5 = Heart; 6 = Stomach; 7 = Eyes; 8 = Intestine; $(+)=$ Organ expressing an antiviral gene; $(-)=$ Organ without expressing antiviral gene 
samples analyzed (without differentiating male and female). Visualization of DNA fragment antiviral gene expression in gel electrophoresis located at approximately $513 \mathrm{bp}$ (Figure 2). The results showed that the hepatopancreas has an important role in the resistance of shrimp against viral infection. It is suspected by closely related to the virus attackment target organ is the hepatopancreas. Number of studies showed the damage of hepato pancreas tissue due to virus attack, especially WSSV (Priatni et al., 2006; Sukenda et al., 2009; Kilawati, 2012). The implication of this study suggested that the antiviral gene isolation can be performed on shrimp hepatopancreas, for easier of getting cDNA antiviral gene. This indicator has been done in previous study where isolation antiviral genes was carried on shrimp hepatopancreas especially survivor shrimp after injected by viral disease. Parenrengi (2010) has isolated an antiviral gene from shrimp hepatopancreas cDNA by RT- PCR technique, in which among the 22 shrimp samples analyzed, 6 samples (27.3\%) showed expression of antiviral gene. The gene has been isolated for characterization and cloning for further research.

The high PmAV gene expression in the hepatopancreas was suspected because of the multiple functions of hepatopancreas as liver and pancreas, where the organ that produces enzymes required in shrimp defense system. Permana et al. (2006) stated the change in histology of the hepatopancreas may be one of indicators of the health status of shrimp both macroscopic and microscopic. Hepatopancreas located in cephalotorax can produce digestive enzymes, store and dispose of the metabolism of the metabolic waste. This organ had an important role in having same function as liver and pancreas in mammals.
According to Karin (2002), the shrimp hepatopancreas consists of closed tubuli in producting enzymes that flowed through the hepatopancreatic duct. In general, the health parameters can ideally reflect the immune function associated with the relevant health conditions which is easier to be measured and observed. Observation of antiviral gene expression in tiger shrimp, especially hepatopancreas provided a general overview of the involvement of these antiviral genes in shrimp immune system. Parenrengi (2010) noted that the results of the study showed that the survivor shrimp from WSSV outbreak has a high resistance to disease virus and has the ability to express the antiviral genes PmAV better than the other shrimp.

The presence of DNA fragments at the position of about 513 bp can be used as a marker of DNA resistant shrimp in a future selection program. Involvement of antiviral genes in shrimp immune system have also been studied by Tenriulo et al. (2010). The study revealed that the expression of antiviral genes PmAV in the shrimp hepatopancreas increased when exposed to WSSV virus. This result suggested that the expression of antiviral genes (up- regulation) increased caused by viral infection. Rantetondok (2011) stated that WSSV virus can cause white spots on the carapace of cultured shrimp, stomach and intestine disorders, fragile and widened hepatopancreas, reddish organs and also the infection shrimp would be death to $70 \% 100 \%$ within $2-7$ days.

Figure 2 showed that the antiviral gene was not only expressed in hepatopancreas, but in stomach. The expression gene in stomach may be indication of the WSSV virus attacked to digestive organs of the shrimp. So, the immune system of shrimp by expressing PmAV antiviral

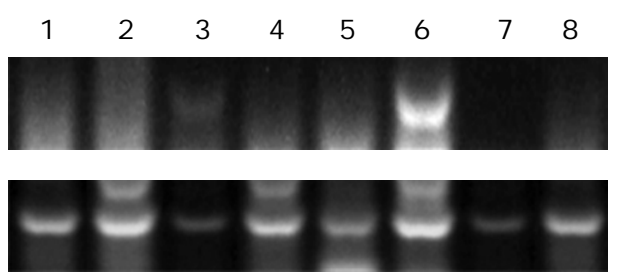

(A)

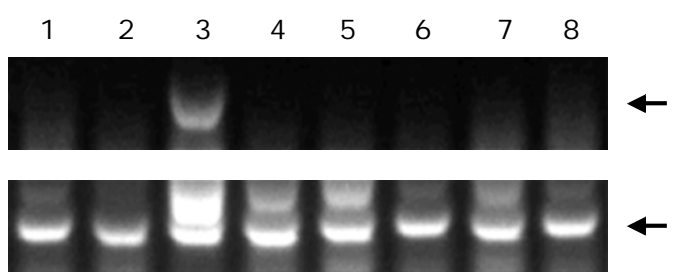

(B)

Figure 2. Electrophoresis of PmAV gene antivirus and internal control $\beta$-actin of female (A) and male (B) tiger shrimp ( $1=$ muscle, $2=$ ovary, $3=$ hepatopancreas, $4=$ gill, $5=$ heart, 6 = stomach, 7 = eyes, and $8=$ intestine; arrow indicating the target gene position) 
genes was performed in order to be able to protect the virus infection. The study conducted by Luo et al. (2007) revealed the expression of antiviral gene at the several organs of the shrimp. The transcription level of PmAV in hepatopancreas was the highest, reaching more than 700 times of that in the muscle, while the mRNA level of PmAV in gill, heart, hemocytes, intestine and stomach was approximately 3-13 times of that in the muscle. Several genes have been widely identified to determine the body's defense mechanisms of fish or shrimp. Ghrelin gene which is a growth hormone gene that is closely linked with immune carp, have been identified by Kato et al. (2007). The gene was expressed in the organ of carps such intestine, spleen, and brain in which gene expression increased after giving immunity astimulation of lipopoliskarida (LPS), phytohemagglutinin (PHA) or imiquimod.

\section{Antiviral Gene Expression on Various Body Size}

Observation of antiviral gene expression has been performed in various group sizes of cultured shrimp in ponds. The presence or absence of antiviral gene expression in a various sizes were based on the presence of DNA fragments at a position approximately $513 \mathrm{bp}$ by PCR technique and $\beta$-actin gene expression shrimp in a position approximately $400 \mathrm{bp}$ was used as an internal control in this study (Figure 3). The thickness expression of DNA gel banding pattern of antiviral gene was varied among individuals and body sizes. DNA fragment of relatively thick was obtained on shrimp size of $30-40 \mathrm{~g}$ for both males and females, compared with the other sizes of tiger shrimp in present study. The thickness of the formed DNA band was naturally illustrated the body's defenses tiger shrimp, which the tiger shrimp having a high expression of antiviral genes would be strong defenses against pathogen infection. Parenrengi (2010) reported that transgenic tiger shrimp showed higher the PmAV antiviral gene expression and the resistance (surviral rate indicator) than normal shrimp when challenged with WSSV virus. The results of study conducted by Somboonwiwat et al. (2006) showed that increasing in expression level of the selected genes in shrimp hemocytes after microbial challenge suggested the involvement of such genes in bacterial response in shrimp. Tenriulo et al. (2009) also reported that the antiviral gene PmAV expression of the shrimp naturally increased the expression when challenged with WSSV virus (up-regulation). However, to strengthen the

(A)

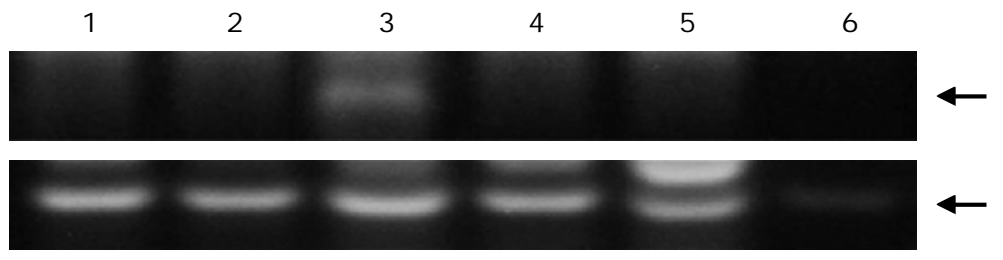

(B)

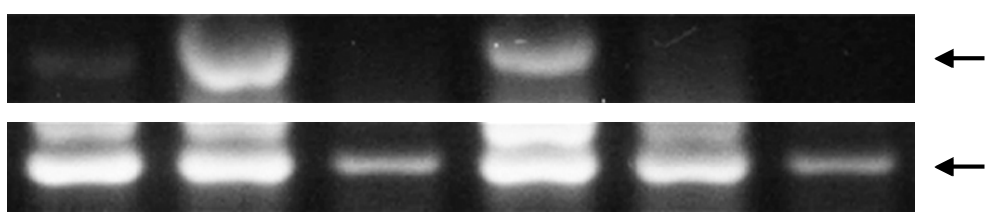

(C)

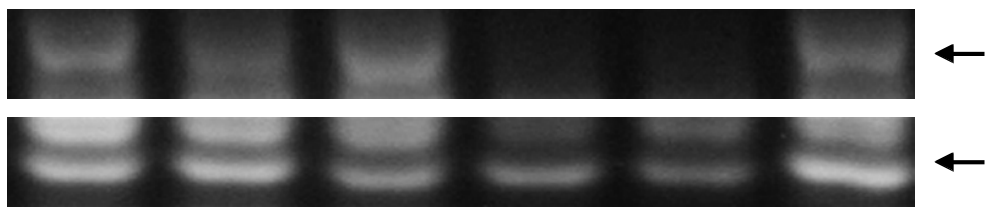

Figure 3. Expression of antiviral PmAV gene in tiger shrimp hepatopancreas at different body weight. (A) Male (1-3) and female (4- 6) tiger shrimp of 10- $20 \mathrm{~g}$; (B) Male (1-3) and female (4- 6) tiger shrimp of 30- $40 \mathrm{~g}$; (C) Male (1- 2) and female (3-6) tiger shrimp of $60-70 \mathrm{~g}$. Gene antiviral expression on the top row and internal $\beta$ - actin gene on the bottom raw, and arrow indicating the position of target gene 
Indonesian Aquaculture Journal Vol.7 No.2, 2012

Table 2. Expression of PmAV antiviral gene on hepatopancreas of tiger shrimp at different body weight

\begin{tabular}{|c|c|c|c|c|c|c|c|c|}
\hline \multicolumn{4}{|c|}{ Male } & \multicolumn{4}{|c|}{ Female } & \multirow{2}{*}{$\begin{array}{c}\text { Total } \\
\begin{array}{c}\text { Antiviral } \\
\text { gene } \\
\text { expression } \\
\text { (\%) }\end{array}\end{array}$} \\
\hline $\begin{array}{c}\text { Weight } \\
\text { (g) }\end{array}$ & $\begin{array}{c}\text { Number } \\
\text { (ind.) }\end{array}$ & $\begin{array}{l}\text { Antiviral } \\
\text { gene } \\
\text { expression } \\
\text { (ind.) }\end{array}$ & $\begin{array}{c}\text { Antiviral } \\
\text { gene } \\
\text { expression } \\
(\%)\end{array}$ & $\begin{array}{c}\text { Weight } \\
\text { (g) }\end{array}$ & $\begin{array}{l}\text { Number } \\
\text { (ind.) }\end{array}$ & $\begin{array}{l}\text { Antiviral } \\
\text { gene } \\
\text { expression } \\
\text { (ind.) }\end{array}$ & $\begin{array}{c}\text { Antiviral } \\
\text { gene } \\
\text { expression } \\
(\%)\end{array}$ & \\
\hline $10-20$ & 3 & 1 & 33.3 & $10-20$ & 3 & 0 & 0 & 16.7 \\
\hline $30-40$ & 3 & 1 & 33.3 & $30-40$ & 3 & 2 & 66.7 & 50.0 \\
\hline $60-70$ & 2 & 2 & 100.0 & $60-70$ & 4 & 2 & 50.0 & 66.7 \\
\hline
\end{tabular}

obious result above, further research on antiviral gene analysis was needed by using real time- PCR (RT- PCR). With RT- PCR technique, Luo et al. (2007) could distinguish quantitative expression of antiviral genes among multiple organs of shrimp.

Percentage of shrimp expressing the antiviral genes was reltively higher $(66.7 \%$ on the larger size $(60-70 \mathrm{~g})$ as compared to medium size $30-40 \mathrm{~g}(50.0 \%$ and the size of $10-20 \mathrm{~g}$ $(16.7 \%$. Six males of tiger shrimp with weigh of $10-20 \mathrm{~g}$ showed only one $(33.3 \%$ antiviral gene expression. The antiviral gene expression on the size of $30-40 \mathrm{~g}$ was obtained in one male $(33.3 \%$ and two females $(66.7 \%)$, and the size of $60-70 \mathrm{~g}$ was obtained on two male (100.0\%) and two females $(50.0 \%$ (Table 2$)$.

Table 2 showed that the bigger size of tiger shrimp would show higher percentage of antiviral gene expression. While, between the male with female of various sizes did not show any differences in antiviral gene expression. The results suggested that the body's defenses of shrimp were not depending on the different of sexs but most probably related to body size and associated with age of shrimp. Bigger body size of shrimp is more likely to have capability to fight pathogens, compare with smaller size. These mean that smaller shrimp is more susceptible to viral infection. Hastuti (2007) noted that the non- specific immunity of tilapia species was strongly influenced by the age and body size of fish.

\section{CONCLUSIONS}

The optimal concentration of primer and CDNA in $25 \mathrm{~mL}$ PCR reaction for antiviral gene expression in shrimp were $50 \mathrm{pmol} / \mathrm{mL}$ and 1 $\mathrm{mL}$, respectively. PmAV gene expression in fe- male was found $66.7 \%$ in shrimp hepatopancreas and $33.3 \%$ in stomach. The higher body size of male and female shrimps tended to show the higher percentage of antiviral gene expression. Using the semi- quantitative PCR technique, expression of antiviral gene PmAV was relatively very low and difficult to visualize. Therefore, to measure the quantity of antiviral gene expression, it is suggested to use Real-Time PCR technique.

\section{ACKNOWLDGEMENTS}

The research was funded by the government budget of DIPA Research Institute for Coastal Aquaculture (RICA) Maros, in 2011. We would like to thank to the all researchers and technicians of Biotechnology Laboratory of RICA, Kadriansyah, and Mariyuliana for supporting the implementation of this study.

\section{REFERENCE}

Anonim. 2003. Petunjuk Pengendalian Penyakit Virus Bercak Putih Pada Budidaya Udang Penaid. Direktorat Kesehatan Ikan dan Lingkungan, Direktorat Jenderal Perikanan Budidaya Departemen Kelautan dan Perikanan. Jakarta, $20 \mathrm{pp}$.

Arenal, A., Pimentel, R., Pimentel, E., Martin, L., Santiesteban, D., Franco, R., \& Alestro, P. 2008. Growth enhancement of shrimp (Litopenaeus schmitti) after transfer of tilapia growth hormone gene. Biotechnol Lett., 30: 845- 851.

Braak, K. 2002. Haemocytic defence in black tiger shrimp (Panaeus monodon). PhD Thesis. Wageningen University- with ref.with summary in Dutch. Nedherlands, 159 pp.

Deachamag, P., Intaraphad, U., Phongdara, A., \& Chotigeat, W. 2006. Expression of a phago- 
Expression of antiviral gene on tiger shrimp at different tissue ... (Andi Parenrengi)

cytosis activating protein (PAP) gene in immunized black tiger shrimp. Aquaculture, 255: 165- 172.

Hastuti, S.D. 2007. Evaluation of non-specific defence of Tilapia (Oreochromis sp.) injected with LPS (Lipopolysaccharides) of Aeromonas hydrophilla. Jurnal Protein, 14(1): 79- 84.

Ito, K., Takizawa, F., Yoshiura, Y., Ototake, M., \& Nakanishi, T. 2008. Expression profile and transcription factor genes during embryonic development of zebrafish Danio rerio. Fisheries Science, 74: 391- 396.

Karin, V.D.B. 2002. Haemocyte defense in black tiger shrimp (Penaeus monodon). Proefscrift, PhD Thesis, Wageninen University, $158 \mathrm{pp}$.

Kato, K., Takagi, M., Tamaru, Y., Akiyama, S.I., Konishi, T., Murata, O., \& Kumai, H. 2007. Construction of an expression vector containing a $\beta$ - actin promoter region for gene transfer by microinjection in red sea bream Pagrus major. Fish Sci., 73: 440- 445.

Kilawati, Y. 2012. Pengaruh serangan WSSV terhadap morfologi, tingkah laku dan kelulushidupan SPF udang vaname Indonesia yang dipelihara dalam lingkungan terkontrol. Laporan Fakultas Perikanan dan Ilmu Kelautan, Universitas Brawijaya, 5 pp.

Kono, T., Kitao, Y., Sonoda, K., Nomoto, R., Mekata, T., \& Sakai, M. 2008. Identification and expression analysis of ghrelin gene in common carp Cyprinus carpio. Fisheries Science, 74: 603-612.

Luo, T., Zhang, X., Shao, Z., \&Xu, X. 2003. PmAV, a novel gene involved in virus resistance of shrimp Penaeus monodon. FEBS Lett., 551:53- 57.

Luo T., Fang, L., Kaiyu, L., \& Xu, X. 2007. Genomic organization, promoter characterization, and expression profiles of an antiviral gene PmAV from the shrimp Penaeus monodon. Mol. Immunol., 44: 1,516- 1,523.

Padmini, E., Usha- Rani, M., \& Vijaya- Geetha, B. 2008. Differential HSP90 expression in fish hepatocytes from polluted estuary during summer. Fisheries Science., 74: 1,118- 1,126

Parenrengi, A., Shamsudin, L., Ismail, P., \& Amin, N.M. 2000. Preliminary study on DNA level marker of grouper at different buffer preservation and DNA extraction method. In Saad, M.S., Faridah, Q.Z., Kadir, M.A., Khalid, M.Z.Z., Mohamad, O., Saleh, G.B., \& Panandam, J.M. (Eds.) Genetic Manipulation: Challenges and Advantages. Proceeding of the $4^{\text {th }}$ National Congress on Genetics, 2628 September 2000. Genting Highlands, Malaysia, p. 194- 208.

Parenrengi, A., Alimuddin, Sukenda, Sumantadinata, K., Yamin, M., \& Tenriulo, A. 2009a. Cloning of ProAV promoter isolated from tiger prawn Penaeus monodon. Indonesian Aquaculture Journal, 4(1): 1- 7.

Parenrengi, A. , Alimuddin, Sukenda, Sumantadinata, K., \&Tenriulo, A. 2009b. Karakteristik Sekuens cDNA Pengkode Gen Antivirus dari Udang Windu, Penaeus monodon. J. Ris. Akuakultur, 4(1): 1- 13.

Parenrengi, A. 2010. Peningkatan resistensi udang windu Penaeus monodon terhadap penyakit white spot syndrome virus melalui transfer gen Penaeus monodon Antiviral. Disertasi Sekolah Pasca Sarjana, Institut Pertanian Bogor, 108 pp.

Permana, G.N., Hutapea, J.H., Moria, S.B., \& Haryanti. 2006. Polimorfisme enzim Glucose- 6 phosphate isomerase pad atiga populasi tuna sirip kuning (Thunnus albacares). J. Fish. Sci., VIII(1): 50- 56.

Priatni, D., Alifuddin, M., \& Djokosetiyano, D. 2006. Pengaruh pemanasan pada temperatur berbeda selama 30 menit terhadap patogenitas white spot syndrome virus (WSSV) pada udang windu (Penaeus monodon Fabr.). Jurnal Akuakultur Indonesia, 5(1): 5- 12.

Qiagen. 1997. PCR optimization: primer design.: 3 hlm.http:// www. qiagen.com / literature/ qiagennews/0597/975 pcro.pdf, accessed on October 11, 2011.

Rantetondok, A. 2011. Penyakit dan Parasit Budidaya Udang/lkan dan Pengendaliannya. Brilian Internasional. Surabaya, 128 pp.

Somboonwiwat, K., Supungul, P., Rimphanitchayakit, V., Aoki, T., Hirono, I., \& Tassanakajon, A. 2006. Differentially expressed genes in hemocytes of Vibrio harveyi-challenged shrimp Penaeus monodon. Journal of Biochemistry and Molecular Biology, 39(1): 26-36.

Sukenda, Dwinanti, S.H., \& Yuhana, M. 2009. Keberadaan white spot syndrome virus (WSSV), taura syndrome virus (TSV), dan infectious hypodermal haematopoitic necrosis virus (IHHNV) di tambak intensif udang vaname Litopenaeus vannamei di Bakauheni, Lampung Selatan. Jurnal Akuakultur Indonesia, 8(2): 1- 8.

Sunandar, D. \& Imron. 2010. Optimalisasi templat DNA genom udang galah, 
Indonesian Aquaculture Journal Vol.7 No.2, 2012

Macrobrachium rosenber gii dalam Proses PCR- RAPD. Loka Riset Pemuliaan dan Teknologi Budidaya Perikanan Air Tawar Subang. Prosiding Forum Inovasi Teknologi Akuakultur, 5: 561-565.

Tenriulo, A., Tonnek, S., Tampangallo, B.R., Widodo, A.F., \& Parenrengi, A. 2010. Analisis Ekspresi Gen Antivirus PmAV pada Udang Windu, Penaeus monodon yang Ditantang dengan WSSV. Jurnal di Balai Riset Per- ikanan Budidaya Air Payau. Makassar, p. 541- 546.

Weeden, N.F., Timmerman, G.M., Hemmat, M., Kneen, B.E., \&Lodhi, M.A. 1992. Inheritance and reliability of RAPD markers. In Applications of RAPD technology to plant breeding, Symposium Proceedings. Crop Science Society of America, Madison, Wl., p. 12- 17. Yuwono, T. 2005. Biologi molekular. Penerbit Erlangga. Jakarta, $269 \mathrm{hlm}$. 